\title{
LEGAL RELATIONSHIP BETWEEN DOCTORS AND PATIENTS IN MEDICAL SERVICE EFFORTS
}

\author{
Endang Kusuma Astuti
}

\begin{abstract}
The relationship between doctor and patient is not equal. The relationship between doctor and patient gave birth to the legal aspects of which object of inspanningsverbintenis is maximum efforts for the recovery / maintaining the health of patients which performed with caution based on the knowledge and experience of the doctor to seek recovery of the patient. Legal relationship between doctor and patient in medical care effort began when the patient filed a complaint which responded to by a doctor. Doctor's responsibility in medical services efforts include ethical, professional, and legal responsibility, which covers doctor's responsibility related to criminal law, civil law and administrative law.
\end{abstract}

Keywords : medical law

\section{A. Introduction}

The medical profession is one of the professions that are gaining public attention. Many people observe medical profession, by commenting directly to the Indonesian Doctors Association as the parent organization of doctors, as well as broadcasting via print and electronic media. The Indonesian Medical Association considers these views as a critique which is useful for the medical profession, so that doctors can improve their medical profession services for the community. Indonesian Doctors Association realized that the criticism is a "tip of an iceberg", meaning that there are many critics who did not come to the surface due to the reluctance of patients or their families thought that what they experienced was something natural. For the Indonesian Doctors Association, the number of public spotlight of the profession of medicine illustrates that people are not satisfied with the health services provided by the doctors. 
Actually the public spotlight on the medical profession is a sign that some people have not been satisfied with the medical care and devotion of the medical profession in the community. In general, the dissatisfaction of the patient and family medical service because their expectations are not met by the doctors, or in other words there is a gap between expectation and reality obtained by the patient.

In Obtaining health care is the right of every human being. The government recognizes that healthy people is an asset and the main goal in achieving a fair and prosperous society. Implementation of health measures carried out in harmonious and balanced by government and society, including the private sector. In order for the implementation of the health effort managed effectively and efficiently, the government should organize, direct and supervise both its efforts and its resources.

Initially the medical profession is a profession that is lauded for his ability to know things that are not visible from the outside. Even a doctor was considered clergy who can cure patients with prayers. ${ }^{1}$

Nowadays doctors are seen as a scientist whose knowledge is needed to cure various diseases. The status and role of doctors are respected, but is no longer accompanied by the element of worship. From the doctors demanded a scientific prowess without forgetting the art and artistic aspects.

Large gaps between the expectations of patients with reality obtained are predisposing factors. Most people are less able to understand that in fact there are many other factors beyond the control of physicians that can affect the results of medical efforts, such as stage of disease, physical condition, endurance, quality of drugs and patient adherence to obey the doctor's advice. These factors can lead to medical efforts (the best ones) become not mean anything. Therefore, it is not wrong if it is then said that the results of a medical efforts full of uncertainty and cannot be calculated mathematically.

\footnotetext{
${ }^{1}$ Van der Mijn. Beroepswetgeving in de Gezondheidszorg. Kluwer : Deventer. 1982. page 33
} 


\section{B. Problems}

From the explanation above, the proposed main issues are as follows:

1. What is the legal relationship between doctor and patient?

2. What are the forms of responsibility on patients in an attempt to medical services?

\section{Research Methods}

Operations or the inner workings of this research is conducted in accordance with the Integrated Paradigm by George Ritzer. Integrated paradigm that emphasizes the attention to modern sociology, may also be directed to the social reality of the macroscopic level, without ignoring the existence and importance of social reality microscopic level. This research conducted by using mixed of doctrinal approach and non-doctrinal approach (sociolegal research). The location in this research take a place in Semarang. Sampling Technique use random sampling for the patients, while for doctors respondents using purposive sampling. Data were collected by using depth interview based on the open questionnaire as complete as possible and participative observation, namely the observation of attitudes, behavior, the situation in the community structure of medical services. Therefore, the primary and secondary data collected in the field to complete further processed and analyzed by the steps of: editing, coding, create categories for the classification of the answers, calculate the frequency, tabs, tables as the data analysis framework. Then data were analyzed by The Mechanical analysis of this study follows the type of Strauss and Corbin, who instructed that qualitative data analysis should be done since being in the field. In a pragmatic move data analysis will be conducted following the model of interactive as stated by Matthew B. Miles and A. Michael Huberman, which requires that research moves into 3 cycles of activity: data reduction, data presentation and conclusion or verification, 


\section{Results and Discussion}

\section{Legal Relationship between Doctors and Patients}

\section{a. The pattern of Legal Relationship between Doctors and Patients}

The relationship between doctors and patients has been going on since ancient times (ancient Greece), the doctor is the one who gives the treatment to the people who need them. This relationship is a personal relationship because it is based on the trust of the patient to a doctor called therapeutic transaction. ${ }^{2} \mathrm{~A}$ personal relationship was described by Wilson ${ }^{3}$ like the relationship between pastor and congregation which was express his feelings. Personal recognition is very important for self-exploration, requires conditions that are covered by the consultation room.

The relationship between doctors and patients originated from such paternalistic pattern of vertical relationships between fathers and children who departed from the principle of "father knows best" which spawned paternalistic relationship. ${ }^{4}$

In this connection, the position of doctors and patients are not equal. The doctor are higher in position than the patient because the doctor considered to know about everything that is associated with the disease and its cure, while the patient did not know anything about it so he then committed herself entirely in the hands of the doctor.

Legal relationship arises when the patient contact a doctor because he felt there was something he felt endangering her health. His psycho-biological state warned that he was feeling sick, and in this case the doctor is considered able to help him, and provide relief aid ("hulpverlenen"). So, doctors are considered in higher position than the position of the patient, and its role is more important than the patient.

\footnotetext{
${ }^{2}$ Al Purwohadiwardoyo. Etika Medis. Kanisius Publisher, Yogyakarta. Page 13

${ }^{3}$ Veronika Komalawati. Peranan Informed Consent Dalam Transaksi Terapeutik. Citra Aditya Bakti, Bandung. 1999. Page 38

${ }^{4}$ Hermien Hadiati Koeswadji. Hukum Kedokteran (Studi Tentang Hubungan Hukum Dalam Mana Dokter Sebagai Salah Satu Pihak). Citra Aditya Bakti, Bandung. 1998. Page 36
} 
Instead, the doctor based on the principle of "father knows best" in this paternalistic relationship will seek to act as a 'good father', who act diligently and carefully to cure the patient. In his attempts to cure these patients, doctors were supplied by the pronunciation of his oath and the Code of Medical Ethics Indonesia.

The pattern of vertical relationships between doctors and patients who gave birth to the paternalistic nature contains both positive and negative impacts. The positive impact of vertical pattern that gave birth to the concept of a paternalistic relationship is very helpful for the patient, in which case the patient lay on his illness. On the contrary it can also be a negative impact, if the actions of doctors which in the form of the steps toward healing the patient was the doctor actions that restrict the autonomy of the patient, which in the history of cultural development and basic human rights have existed since birth. Vertical The pattern of paternalistic relationship is shifted in a horizontal pattern contractual.

This relationship gave birth to the legal aspects of horizontal contractual nature "inspanningsverbintenis" ${ }^{5}$ which is a legal relationship between the two legal subjects (patients and physicians) who have equal positions created rights and obligations for the parties concerned. This legal relationship is not promising anything (recovery or death), because the object of the legal relationship in the form of maximum effort undertaken carefully and tense by the doctor based on science and experience (dealing with the disease) to cure the patient.

\section{b. Occurrence of Legal Relationship between Doctors and Patients}

Legal relationship contractual occurred between patients and doctors is not started from the moment the patient enters the doctor's office as alleged by many people, ${ }^{6}$ but rather from the time the doctor expressed willingness orally (oral statement) or implicit (implied statement) by showing the attitude or actions which

\footnotetext{
${ }^{5}$ Ibid. page 37

6 Sofwan Dahlan. Hukum Kesehatan Rambu-Rambu Bagi Profesi Dokter. BP UNDIP, Semarang. 2000. page 32-33
} 
concluded willingness; such as accepting registrations, giving the serial number, provide and record their medical records and so forth. In other words, the therapeutic relationship also requires the willingness of doctors. This is in accordance with the principle of consensual and contract.

\section{c. Terms of the therapeutic transactions}

Terms of the therapeutic transactions are based on Article 1320 Civil Code, who states that for the validity of the agreement, required four (4) criteria to be met as follows: ${ }^{7}$

\section{1) Agreed they who were bound themselves (toestemming van degene die zich verbinden)}

Legally, definition of the existence of an agreement is the absence of mistake, or duress, or fraud (Article 1321 Book of Civil Law).

Occurrence of the agreement, related to Article 1320 Code Civil Code, is the time of the agreement between the doctor and patient when the patient stated that his complaint and responded to by a doctor. Here, doctor and patient mutually bind themselves to an agreement that the object is a therapeutic healing effort. When healing is a main goal it will be difficult for doctors because of the severity of disease and the body's resistance to any drug the patient is not the same. The same drug cannot be sure the same results on each patient.

\section{2) Skills to create engagement (bekwaamheid om eene verbintenis aan te gaan)}

Legally, the definition of skills to create engagement is a person ability to bind himself, because it is not prohibited by law. This is based on Article 1329 and 1330 Book of Civil Law.

Article 1329 Book of Civil Law stated that everyone are skilled to create engagement, if not declared otherwise by law. It is explained in Article 1330 Book of Civil Law which stated that those who are declared not skilled are minors, those

\footnotetext{
${ }^{7}$ Veronika Komalawati. 1999. op.cit. page 155
} 
who are under guardianship, women, stated by law and generally those who are forbidden by law to create certain agreement.

Receiver of medical services consist of adults who are skilled to act, adults who are not skilled to act, those who need approval from their guardian, and children who are under age and need approval from their parents or guardian. There are various regulations in Indonesia that mention maturity age limit, those are:

a) Minors are those who have not reached age 21 and not married (Article 330 Book of Civil Law), meaning mature are those who are 21 years old or have been married even if it have not reached age 21 yet. If the marriage is broken while not reached age 21 , it will be in immature state.

b) Act No. 1 of 1974 on Marriage, article 47 paragraph (1) states that a child who has not reached 18 years of age or have never establish marriage under authority of his parents as long as they are not deprived of his power. Paragraph (2), states that parents represent the child in all legal actions on and off the court. Then Article 50 paragraph (1), states that a child who has not attained the age of 18 years or have never establish a marriage, which is not under parental authority, under the authority of a guardian. Paragraph (2), states that this guardianship of the child as well as personal possessions.

c) In Chapter XIV Compilation of Islamic Law promulgated by presidential order No. 1 of 1991 dated June 10, 1991 on the Child Maintenance Article 98 stated:

(1) Age limit for child / adult who is able to stand alone is 21 years old, not physical or mental defect or have establish marriage (paragraph (1)).

(2) Parents who represent the child in all legal actions on and off the court (paragraph (2)).

(3) The court may appoint one religion a close relative who is able to fulfill those obligations if both parents cannot afford (paragraph (3)).

Of various regulations mentioned above turns out there are some rules that mention the age of 21 years as a mature age limit. Similarly, adult limits specified 
in Article 8 paragraph (2) of the Regulation of the Minister of Health No. 585 / Men.Kes / Per / IX / 1989, followed the Decrees of Medical Services 21 April 1999 which states that adult patients referred to paragraph (1) is 21 years old or have been married.

\section{3) One particular thing (een bepaald onderwerp)}

Certain things that can be linked to the object of the agreement / transactions are therapeutic healing effort. Therefore, the object is the recovery efforts, the results obtained from the achievement of these efforts can not or should not be guaranteed by a doctor. Moreover, the implementation of the recovery efforts was not only depend on the seriousness and expertise of doctors in carrying out their professional duties, but many other factors come into play, for example durability patients to a particular drug, severity of disease and the role of patients in carrying out the doctor's orders for the sake of patients itself.

\section{4) A valid reason (geoorloofde oorzaak)}

Article 1337 Book of Civil Law states that a cause is illicit, when prohibited by law or if contrary to good morals or public order. Thus, the meaning of valid reason is because that is not prohibited by law, morality or public order,

\section{d. Informed Consent}

Informed consent includes about information and approval, which approval is given after the concerned being informed beforehand. Based on Permenkes $585 / 1989$, it is said that informed consent is consent given by patients or their families on the basis of a description of the medical procedure to be performed on these patients.

In essence, human relations cannot occur without communication, including the relationship between doctor and patient is an interpersonal relationship, the 
communication, or better known as therapeutic interview is very important. King's ${ }^{8}$ research results prove that in the entire essence of the relationship between doctor and patient lies in a therapeutic interview. In the interview the doctors are expected to fully inform the patient about the kind of action that will be or needs to be performed as well as its risks.

Medical language uses many foreign terms that are difficult to understand by the public. Provision of information by using medical language, would not bring any results, in fact it would confuse the patients. Therefore, the information should be given by a doctor to a patient in a language, which is simple and easily understood by the patient.

Once the information is given, it is expected that there is consent from the patient, in terms of the patient's permission to carry out medical action. Patients have the right to accept or refuse treatment for himself, this is a human right that includes the right of patients to self-determination and the right to information.

Therefore, the approval given by the patients require some input as follows: ${ }^{9}$ 1) A full description of the procedures to be used in the medical action specified (which is still in the form of attempts, trials) proposed by the doctor and the objectives to be achieved (the result of the effort, experimental), 2) A description of the side effects and unwanted consequences possible, 3) Description of the benefits that can be anticipated for / to the patient, 4) A description of the expected duration of the procedure, 5) Description of the the patient's right to withdraw consent without prejudice about his relationship with the doctor and the institution. 6) The prognosis of the patient's medical condition when he refused a particular medical procedure.

Form of informed consent can be either express or tacit. Expressed informed consent can be delivered by direct words either verbally or in writing and

\footnotetext{
${ }^{8}$ Foster and Anderson. Antropologi Kesehatan. Universitas Indonesia Press, Jakarta. 1986. page 140-141

${ }^{9}$ Hermien Hadiati Koeswadji. 1998. op cit. page 74
} 
informed consent conducted secretly, among others nod or actions that imply acquiescence.

Informed consent was done orally if it is low-risk medical procedure, for example in administration of drug treatment and medical investigation. As for the medical measures that contain high risk, such as surgery, the informed consent must be made in writing and signed by the patient.

It is the safest for the doctor when consent is expressed in writing, so that there is a document that can be used as evidence if one day questioned. This latter way is not practical so most doctors only use this method if the medical procedure to be performed have a high risk or have an effect of which are not pleasant.

In developed countries, various written consent forms were deliberately provided in every hospital. Apparently the experience sue and be sued in making them more cautious, to the point of blood transfusion are also provided its own form. In principle, the form provided shall contain an acknowledgment that the party concerned has been informed and fully understand and agree to the medical treatment recommended by doctors.

Something that should not be overlooked is when providing information must not be deceitful, suppress or create fear because his all three would make the approval given be flawed.

Information should be given by the doctor who will perform certain medical acts, because only he himself knows exactly about the patient's condition and all the ins and outs of the medical procedure to be performed. It can be delegated to other doctors or nurses, but if there was an error in providing information then the person who should be responsible for the mistake is doctor who performs medical actions. Moreover, in the process of obtaining patient consent, does not cover the possibility of a discussion that requires an adequate understanding of the party providing the information.

Most doctors believe that informed consent is a tool that can free them from responsibility in case of malpractice. This assumption is a big mistake and 
misleading considering malpractice is another issue that is closely related to the implementation that does not comply with the standards. Although they already have informed consent, but if its implementation is not compliant, the doctors still have to be responsible for any losses incurred.

From the point of criminal law, informed consent must be met. This is related to the existence of Article 351 of the Criminal Code, about the persecution. A surgery performed without the consent of the patient, can be termed as torture and thus constitute a violation of Article 351 of the Criminal Code. Leenen give an example (as quoted by Ameln ${ }^{10}$ ), when A stab / slash a knife to B causing wound, then that can be termed as persecution. If $\mathrm{A}$ is a doctor, such action remains the persecution, except: 1) the person who were injured (patient) has approved. 2) The medical measures (surgery, which essentially also slashing, stabbing, cutting the patient's body) is based on a medical indication. 3) Medical action was conducted in accordance with the rules of medical science recognized in the medical world.

From the point of civil law, informed consent must be fulfilled. It is concerned that the relationship between doctor and patient is a tie (therapeutic transactions) should qualify as a valid agreement mentioned in Article 1320 Civil Code, among which is an agreement between doctor and patient. Patients may express agreement if he had been given information from the doctor to the treatment that will be given as well as the side effects and risks. It is also associated with the second element of the conversation in making the engagement. This is related to the provision of information from doctors to patients who are immature or placed under guardianship, that information was given to parents or guardians

In principle, the requirements to obtain informed consent in certain medical acts are not differentiated by informed consent required in an experiment. However, in a research experiment both therapeutic and non-therapeutic use of patients as subjects, the informed consent must be sharpened, because it involves

${ }^{10}$ Fred Ameln. Kapita Selekta Hukum Kedokteran. Grafikatama Jaya, Jakarta. 1991. page 44 
the protection of human dignity, prevention of coercion, error and abuse of situation.

\section{The Doctor's Responsibility toward Patients}

\section{a. Ethical Responsibility}

Rules governing the ethical responsibility of a physician are the Code of Medical Ethics Indonesia and pronunciation of the Doctor's Oath. Indonesia Code of Ethics issued by the Minister of Health Decree no. 434 / Men.Kes / SK / X / 1983. Code of Medical Ethics Indonesia is structured based on the International Code of Medical Ethics with the ideal basis of Pancasila and the structural foundation of the Constitution of 1945. Indonesia's Code of Medical Ethics regulate human relationships that includes a general obligation of a doctors, doctors relationships with patients, doctors obligations against his colleagues and obligations of doctors towards himself.

Violations of the Code of Medical Ethics Indonesia there is only a purely ethical violation and there is also an ethical violation and simultaneously a violation of law. Violations of ethics does not always mean a violation of law, violation of the law on the contrary does not necessarily constitute a violation of medical ethics. Here are presented some examples

\section{1) Pure ethical violation}
a) Taking rewards unnatural or taking fees from colleagues family doctors and dentists.
b) Taking over the patient without the consent of his colleagues.
c) Praise yourself in front of the patient
d) Never follow a continuous medical education
e) Doctors neglect their own health

\section{2) Ethics and legal violations}

a) Below standard medical services 
b) Issuing fake credentials

c) Unlock the official or professional secret of doctor

d) Abortion provocation

e) Sexual harassment

\section{b. Professional Responsibility}

The responsibility of the medical profession is closely related to the professionalism of a doctor. It is associated with: ${ }^{11}$

\section{1) Education, experience and other qualifications}

In carrying out the task of his profession, a doctor must have a degree of education in the occupied areas of his expertise. On the basis of the knowledge obtained during education in the faculty of medicine and specialization and experience to help sufferers.

\section{2) The degree of risk of treatment}

The degree of risk of treatment sought for the smallest, so that the side effects of treatment kept to a minimum. In addition, the degree of risk of the treatment should be notified to the patients and their families, so that patients can choose the alternative of treatment advised by the doctor.

Based on data from physician respondents, found that information regarding the degree of care there are obstacles to patients or families with low education levels, having been given the information but he could not catch it well.

\section{3) Equipment for treatment}

Importance used inspection using equipment maintenance, if the examination results obtained outside less accurate results required inspection equipment. But the answer of the respondents indicated that not all patients are willing to be

\footnotetext{
${ }^{11}$ Hermien Hadiati Koeswadji. op cit. page 131
} 
examined by using tools (advanced medical devices), it is associated closely with the costs to be incurred for the economically weak patients.

\section{c. Legal Responsibility}

The legal responsibility of a doctor is an "bound" doctors against legal provisions in their profession. The responsibility of a doctor in the field of law is divided into three (3) sections, namely: ${ }^{12}$

\section{1) Civil Responsibility}

\section{a) Legal Responsibility in Breach of Contract}

Definition of default is a condition where a person does not fulfill its obligations based on an agreement or contract. Basically, the civil responsibility is to obtain compensation for losses suffered by patients as a result of default or tort of the actions of doctors.

According to the civil law, a person can be considered in default if: Do not do what is affordable to be done, do what is promised but delayed and implement what was promised, but not as promised and do something that according to the agreement should not be done.

In connection with this issue, then the default is the civil responsibility of a doctor is not meeting the requirements set forth in an agreement which he had held with his patients.

Lawsuit to pay compensation on the basis of agreement or treaty that occur can only be done if there is an agreement between doctors and patients. The agreement can be classified as an agreement to do something. It occurs when the patient's agreement to call a doctor or go to the doctor, and the doctor meet the demand of patients to treat. In this case the patient would pay some fees. While doctors should actually be performing feats cure patients of the disease. But healing is not always the case, so that doctors only bind himself to provide help as much as

\footnotetext{
12 Ninik Maryati. Malpraktek Kedokteran dari Segi Hukum Pidana dan Perdata. P.T. Bina Aksara, Jakarta. 1988. page 5
} 
possible, according to the knowledge and skills mastered. That is, he promised to make an effort as strong as possible to cure the patient.

In the suit on the grounds of breach of contract, it must be proven that the doctor was actually entered into an agreement, then he has been in default on the agreement (which is of course in this case continues to be based on professional misconduct). So here the patient must have evidence of loss due to non-fulfillment of obligations of physicians in accordance with applicable standards of medical profession in a therapeutic contract. But in practice it is not easy to carry out, because the patient does not have enough information from his or her doctor about what actions might constitute an obligation of physicians in a therapeutic contract. It is very difficult to proof because given the engagement between physicians and patients is to be inspanningsverbintenis.

\section{b) Legal Responsibility in Actions against the Law (onrechtmatige daad)}

The responsibility for mistakes is the classic form of civil responsibility, based on the three principles set out in Article 1365, 1366, 1367 Civil Code is as follows:

\section{(1) Article 1365 Civil Code}

Patients can sue a doctor because doctors have committed acts that violate the law, as set out in Article 1365 of the Civil Code which states that: "Every act of breaking the law, which brings harm to others, require a person who due to his fault causing the error it is, replace the loss ".

Law did not impose limits on tort, which must be interpreted by the judiciary. Originally meant anything contrary to the law, so an act against the law. But since 1919, established jurisprudence has given the sense that any act or omission either: (1) Violating the rights of others (2) Contrary to the legal obligations of their own (3) violates ethical view generally shared (customs good) (4) not in accordance with the compliance and accuracy as the requirements of the self and the object in a social life. 
A doctor can commit a mistake. To determine an offender against the law must pay compensation, it must be a close connection between the fault and the losses incurred

\section{(2) Article 1366 Civil Code}

A doctor besides being able to be prosecuted based on breach of contract and unlawful acts as mentioned above, can also be prosecuted on the basis of negligent, causing losses. The lawsuit on the basis of negligence is governed by Article 1366 Book of the Law of Civil Law, which reads as follows: "Everyone is responsible not only for the harm caused by his actions, but also for the loss caused due to negligence or carelessness".

\section{(3) Article 1367 Civil Code}

Someone has to give responsibility not only for damages from his own actions, but also for losses incurred from the actions of others who were under his supervision. (Article 1367 of Civil Code). In this case, the parents or guardians are responsible for children who are minors or who are under guardianship, also the employer of persons who represented his business (which became its power), and the responsibility is lost or terminated if they can prove that they cannot prevent acts under his responsibility.

Thus, in essence, the provisions of Article $1367 \mathrm{BW}$ governing the payment of compensation by the party who orders the work caused financial losses to the other party.

"Nuboer Arrest" is a good example in terms of doing a medical act in a team bonding. But from the Arrest should be learned some sense to be able to follow the matter further. When linked with the provisions of Article $1367 \mathrm{BW}$, it first needs to be held identification of the extent to which civil responsibility assistant of Prof. Nuboer. First known who is meant by subordinates. As for what is meant by a subordinate in the sense contemplated by Article 1367 BW are parties 
who are not able to act independently in relations with his superiors, because it requires supervision or further specific instructions. If the physician acts associated with the provision of Article $1367 \mathrm{BW}$, it is the doctor's responsibility is very broad, although in reality the division of tasks within the team relationship is not as it was intended by the provisions of Article $1367 \mathrm{BW}$. However, the provisions of Article 1367 BW still provide opportunities, namely if a doctor can prove that they cannot prevent the actions under its responsibility.

In this connection, a doctor should be responsible for the actions committed by his subordinates, namely nurses, midwives, and so on. Errors of nurses for running a doctor's orders are doctor's responsibility. From the statements of the respondents obtained the data that in some hospitals in areas with no anesthesiologist on it, then the failure of anesthesia performed by a nurse anesthetist is the responsibility of the doctor. Similarly, the delegation of authority given by the doctors to midwives attending births is the responsibility of the doctor.

\section{2) Criminal Responsibility}

Along with the increasing awareness of the importance of law, in the subsequent development raised the question of criminal responsibility of a doctor, especially regarding the omission, where it is based on theories of guilt in criminal law.

Criminal responsibility arises if it can be proven the existence of professional misconduct, for example, errors in diagnosis or errors in the ways of treatment or care.

From a legal standpoint, error / omission will always be linked to the nature of its unlawful acts committed by a person who is able to take responsibility. A person is said to be responsible if it can realize the actual meaning of his deeds, can realize his actions were deemed inappropriate in the community and were able to determine the intentions / her will in committing such acts. 
An act can be categorized as criminal malpractice, if it meets the formulation of a criminal offense, namely: The act must be a disgraceful act and performed with the wrong mental attitude in the form of intent, recklessness or negligence.

Errors or omissions committed by health personnel can occur in the field of criminal law, among others in: Article 263, 267, 294 paragraphs (2), 299, 304, 322, 344, 347, 348, 349, 351, 359, 360, 361, 531 Book of Law Criminal Law.

There is an important difference between ordinary crimes with 'medical criminal offense'. In ordinary crime is concerned is 'the result', whereas in the medical criminal offense is 'the cause'. Although fatal, but if there is no element of negligence or fault of the doctor is not to blame.

Some examples of criminal malpractice in the form of intent is to have an abortion without medical indication, divulge the secret of medicine, did not help someone who is in a state of emergency, perform euthanasia, published an incorrect medical certificate, make an incorrect post mortem and provide incorrect information before the court in the capacity as an expert.

In the literature of medical law Anglo-Saxon countries, among others, Taylor ${ }^{13}$ said that a new doctor can be blamed and sued under the law if he had qualified, namely: Duty, Derelictions of That Duty, Damage, and Direct Causal Relationship.

Duty or obligation may by agreement (ius contractu) or by law (ius delicto). Liabilities doctors to work based on professional standards. Now is the duty of physicians to obtain informed consent, in the sense required to provide sufficient information and understanding before taking action? That information includes, among others: risks inherent in the action, the possibility of side-effects, other alternatives if there is, what is the result if it is not done and so on. Rules on informed consent are already regulated in Regulation of the Minister of Health No. 585 of 1989.

13 J. Guwandi. Dokter dan Rumah Sakit. FK UI. 1991. page 48-49 
The determination that deviates from the medical profession standard (Dereliction of The Duty) is something that is based on facts that should be considered by experts and expert witnesses. But often patients confound between result and negligence, that the incidence of negative effects or the patient's condition is not improving yet prove negligence. Negligence must be clearly demonstrated. It must be proven first that the doctor had committed 'breach of duty'.

Damage means the losses suffered by patients and should be tangible in the form of physical, financial, emotional or any other loss categories. In the literature distinguished: general damages including loss of revenue to be received, pain and suffering; special damages that the real financial loss to be incurred, such as medical expenses, salaries are not accepted.

Conversely, if there is no loss, then also no reimbursement of loss. Direct causal relationship means that there must be a causal link between the actions of the losses suffered.

\section{3) Administrative Responsibility}

Administrative malpractice is the act of a doctor violated administrative law. Examples of the actions of doctors who are classified as administrative malpractice is practicing without a license, perform medical actions that are not in accordance with permit owned, practice using licenses that have expired and not make medical records.

Under existing rules, a person who has graduated as a doctor does not automatically allowed to do the work of doctors. He must first take care of the license in order to obtain the authority, in which each type of license requiring basic science and each have their own authority. It is not justified to perform medical procedures overreaching its predetermined. Although a gynecologist is able to perform tonsillectomy but his license does not justify the medical measures. If these provisions are violated, the doctor can be considered to have committed 
administrative malpractice and may be subject to administrative sanctions, for example in the form of suspension of the license for a while.

Article 11 of Law No. 6 In 1963, administrative sanctions may be imposed against the doctors who neglect obligations, doing something that should not be done by a doctor, either recall the oath of office and given his oath as a doctor, ignoring something that should be done by physicians and in violation of the provisions under the Act No. 6 of 1963.

\section{E. Conclusion and Recommendation}

\section{Conclusion}

a. Legal relationship between doctor and patient in medical care effort which is based on trust of patients to the doctor begin when the patient filed a complaint which is then taken up by the doctor

b. Legal responsibility on patients in medical services efforts include:

1) The responsibility of ethics, namely concerning moral profession summarized in pronunciation Oath Physicians and spelled out in the Code of Medical Ethics Indonesia

2) The responsibility of the profession is the responsibility associated with the medical profession that involves the ability and expertise of doctors in carrying out his profession

3) Responsibility covering three areas of law

a) Civil law relating to the rules in the Civil Code of default related to the terms validity of a treaty stipulated in Article 1320 of the Civil Code, and the tort (onrechtmatige daad) set out in article 1365, 1366 and 1367, the physician must be responsible for any errors or negligence and carelessness in performing his professional duties, and doctors should be responsible for errors committed by his subordinates who committed the act on his orders. 
b) The criminal law, because no professional errors that errors in diagnosis and therapy as well as certain medical action that must meet four requirements, namely Duty, Dereliction of Duty That, Damage, Direct Causal Relationship consisting of either intent or negligence.

c) Administrative law, with regard to the administrative requirements relating to the authority of doctors in carrying out his profession.

\section{Recommendations}

In order to reduce medical disputes between doctors and patients, doctors in carrying out their profession should not guarantee the results of treatment; doctors are expected to provide services that meet the expectations of patients namely informative, humane and qualified treatment in accordance with the standards of the profession, and the doctor had to constantly improve his skills through courses, seminars and symposia as well as in providing an explanation for the patient to use simple language to be easily understood by the patient.

Patients need to understand that the legal relationship between doctor and patient that gave birth to the legal aspects inspanningsverbintenis because the object of the legal relationship it is the maximum effort by doctors carefully is based on his knowledge to cure the patient. So, it did not promise a sure thing.

\section{References}

Ameln, Fred. 1991. Kapita Selekta Hukum Kedokteran ,Grafika Tama Jaya.

Anderson \& Foster. 1986. Antropologi Kesehatan Universitas Indonesia Press, Jakarta.

Dahlan, Sofwan. 2000. Hukum Kesehatan. Rambu-Rambu Bagi Profesi Dokter. BP UNDIP, Semarang

Guwandi, J.. 1991. Hukum dan Rumah Sakit. FK UI, Jakarta.

Koeswadji, Hermien Hadiati. 1998. Hukum Kedokteran (Studi Tentang Hubungan Hukum Dalam Mana Dokter Sebagai Salah Satu Pihak). PT. Citra Aditya Bakti, Bandung.

Komalawati, Veronika. 1999. Peranan Informed Consent Dalam Transaksi Terapeutik. Citra Aditya Bakti, Bandung. 
Maryati, Ninik.1988. Malpraktek Kedokteran dari Segi Hukum Pidana dan Perdata. P.T. Bina Aksara, Jakarta.

Mijn, Van Der. 1982. Beroepswetgeving in the Gezondheidzorg. Kluwer, Deventer.

Parsons, Talcott. 1977. Social System and The Evolution of Action Theory. The Free Press. A division of Macmillan Publishing Co. Inc, New York

Purwohadiwardojo, Al. 1989. Etika Medis. Kanisius, Yogyakarta. 